\title{
AN EMPIRICAL STUDY OF FACTORS AND COGNISANT MEASURES FOR PROJECT QUALITY IN THE DESIGN PHASE: A CASE OF BUILDING PROJECTS IN THE DEPARTMENT OF BUILDING AND ENGINEERING SERVICES OF BOTSWANA
}

\author{
E.N.D. Dodoo ${ }^{1}$, C.C. van Waveren ${ }^{2}$ and K-Y. Chan ${ }^{3 *}$ \\ 1,2,3 Graduate School of Technology Management \\ University of Pretoria, South Africa \\ corro@up.ac.za, alice.chan@up.ac.za
}

\begin{abstract}
There were numerous complaints regarding the quality of building projects performed by the Department of Building and Engineering Services (DBES) in Botswana. This empirical study has two objectives: first, to evaluate participants in DBES projects by using 16 identified factors in the project design phase that may influence the quality of building projects; second, to explore the inter-relationships between the 16 factors in the project design phase and the five measures of which the design phase takes cognisance. The study applied a quantitative research methodology. A total of 115 survey questionnaires were distributed to collect data. A descriptive and a multivariate analysis was performed.
\end{abstract}

\section{OPSOMMING}

In Botswana was daar verskeie klagtes ontvang aangaande die kwaliteit van bouprojekte soos uitgevoer deur die Departement van Bou- en Ingenieursdienste (DBES) in Botswana. Twee doelwitte is vir hierdie studie gestel: Eerstens om deelnemers in DBES projekte te evalueer aan die hand van 16 geïdentifiseerde faktore ten opsigte van die kwaliteit van bouprojekte tydens die ontwerpfase van hierdie projekte; en tweedens om die verwantskap te ondersoek tussen die 16 faktore in die ontwerpfase van bouprojekte en die vyf maatstawwe wat tydens die ontwerpfase in aanmerking geneem word. ' $n$ Kwantitatiewe navorsingsmetodiek is tydens hierdie studie gebruik, waar ' $n$ totaal van 115 vraelyste uitgestuur is. ' $n$ Beskrywende en meerveranderlike analise is uitgevoer.

\footnotetext{
${ }^{1}$ The author was enrolled enrolled for a MEng (Project Management) degree in the Graduate School of Technology Management, University of Pretoria)

${ }^{*}$ Corresponding author
} 


\section{INTRODUCTION: MOTIVATION OF THIS STUDY AND ITS AIMS}

The Department of Building and Engineering Services (DBES) in Botswana is a merger of the previous Department of Architecture and Building Services (DABS) and Department of Electrical and Mechanical Services (DEMS). The newly merged department, DBES, is responsible for the implementation of government building infrastructure development projects. DBES has a pure project management structure: people working on a project are grouped together under a project manager who reports to an executive officer. It appears that the merging of the two departments has not led to better project quality, and there were numerous complaints about DBES building projects. This paper aims to evaluate participants in DBES projects against project success factors in order to identify key focus areas. Project success factors often fall into two groups: project planning and subsequent tactical operations, or implementation [1]. In previous research, the project design phase was found to have a great impact on overall project quality [2]. This paper identified 16 factors during the design phase that may influence the quality of projects. During the design phase, certain aspects are considered to ensure project success - constructability, for example, which may reduce the need for revision and changes during project execution $[3,4]$. This study takes into account five aspects or measures of which the design phase of DBES projects should take cognisance. Moreover, the underlying relationships (using multivariate analysis) between the 16 factors and the five measures during the project design phase will be uncovered. The remainder of this paper is structured as follows: A short description of the DBES in Botswana is provided in Section 2. Section 3 provides a brief background to the factors (during the project design phase) that may influence project success, and the aspects of which the project design phase take cognisance (denoted as cognisant measures). Section 4 describes the research methodology used. The statistical results are reported in Section 5 . The final section provides recommendations for managers and for future studies.

\section{DBES IN BOTSWANA}

The Republic of Botswana is situated in Southern Africa, nestled between South Africa, Namibia, Zimbabwe, and Zambia. The country is democratically ruled, and boasts a growing economy and a stable political environment. Botswana's economic progress since independence has been one of the few success stories of the African continent. According to the World Bank (in Economic Indicators 2004), twenty years ago the country was one of the 20 poorest countries in the world. Anderson [5] states that today Botswana is considered to be the richest non-oil producing country in Africa. Botswana has seen a substantial and consistent growth in its GDP, with a corresponding increase in development activities, processes, and projects in the country. This has led to a consistent growth in the construction industry, stimulated by many government projects initiated by its ministries. The increase in the number and complexity of the projects being implemented severely strained the resources of the two departments concerned, the Department of Architecture and Buildings Services (DABS) and the Department of Electrical and Mechanical Services (DEMS). Projects run by these two separate departments had huge cost overruns, took too long to complete, and were at times seen to be of poorer quality. The Botswana Government constituted two consortia - the Organisation Capacity Assessment (OCA) study and the Operational Efficiency Improvement (OEI) study - to review project management procedures and the organisational structure with a view to improving project delivery and efficiency.

Following the study, the Botswana Government decided to merge the DEMS and the DABS, believing that merging the two departments would lead to improved project delivery, and in particular to implementing projects within budget and time, and meeting clients' expectations with high performance. The merger of the two departments took place in 2004, creating the Department of Building and Engineering Services (DBES). The DBES's organisational structure is a pure project management structure. According to Steyn et al. [6], in a pure project or 'projectised' structure, people working on a project are grouped together under a project manager who reports to an executive officer. They indicated that 
the pure project structure is preferred where projects are large and have a long duration. Moreover, when a project is of great strategic importance and it is important to complete the project within a short time, a pure project organisation structure should be considered for such a project. DBES employs about 168 professional staff and operates through three core divisions: the Project Implementation Division (PID), the Technical Services Division (TSD), and the Maintenance Division (MD). Other divisions or sections provide support services. The DBES defines its vision and mission in these terms:

"The Department will be a model of excellence in the delivery and maintenance of public buildings, engineering infrastructure and related services to the full satisfaction of our stakeholders." (Vision)

"The Department will provide building and related services in partnership with stakeholders to client ministries/departments consistent with National Development Plans and other Government Policy pronouncements. We commit ourselves to local capacity building within time with available resources and to acceptable standards." (Mission)

The merging of the two departments has not led to any significant reduction in delays and cost overruns of projects, and so its quality remains unacceptable. This study will look at the factors that influence project quality in the design phase of building projects, with a specific focus on projects in the Department of Building and Engineering Services (DBES). A justification for the study of the factors that influence the quality of a project in the design phase of projects is that incorrect and defective designs do have an enormous impact on the successful implementation of building projects. The quality of designs influences the implementation of the project, and thus the success or failure of the project. To a large extent the satisfaction that the end-user derives from a completed building depends on the quality of the input at the initial stages of the design. To allow the contractors to transform the design concepts and ideals into a physical product, the designers must provide wellillustrated drawings and detailed specifications. Any attempt to improve on the quality of designs at the design phase of the project will consequently improve the construction process and produce a building that will meet the end-user's expectations. In addition, the study of the factors that influence the quality of design will create an awareness of quality of design in the project sponsors, leading them to allow sufficient project resources at the early stages of the project.

\section{RESEARCH FRAMEWORK}

There are two parts in this section: first, the factors that influence project quality in the design phase of building projects; and second, the aspects of which the design process takes cognisance (called 'cognisant measures').

\subsection{Factors that influence project quality in design phase}

Building projects start with the project design phase, which "translates the primary concept into an expression of a spatial form which will satisfy the owner's requirements into an optimum and economic manner" [2]. During the project design phase the objectives, constraints, and specifications of the project are defined by a team of individuals [7]. In building projects many uncertainties could be eliminated during the early stage by addressing the scope of the project, the deliverables, the cost involved, and the schedule for delivery [6]. Effective management for project quality starts when the deliverables (which satisfy the need) are determined in this phase [8]. Customer satisfaction is considered one of the four project quality pillars that emerge from the conceptual foundation [9], and thus customer / user requirements at the initial stages of projects (i.e., the design phase) should be specified or clearly defined to avoid design deficiencies that may cause contract modifications during the implementation of the project [10]. 
In this study the authors identified three categories of factors in the project design phase that may influence project quality: project management principles, involvement of role players, and project scope.

\subsubsection{Project management principles}

These principles are most often learnt from experience, and may be applied to all projects to ensure success. In this study the following principles to be included during the design phase of DBES's projects have been identified:

- DBES's process to select the design team to meet the client's requirements and expectations;

- $\quad$ adherence to design brief from clients;

- $\quad$ DBES's commitment to continuous quality improvement;

- DBES leadership's commitment to adhere to procedures and specifications at the design phase;

- $\quad$ comprehensiveness of drawings and specifications;

- $\quad$ visibility of the total life cycle cost during the design phase; and

- $\quad$ use of lessons learned to improve the quality of designs.

\subsubsection{Involvement of role players}

Inputs from project participants (role players) during the design phase will clarify the project's scope, planning, and scheduling, and eliminate uncertainties in the future [11]. The involvement of the following role players during the design phase is important to DBES project quality:

- $\quad$ Building contractors

- $\quad$ End-users

- Management of DBES

- Other stakeholders

\subsubsection{Project scope}

Inadequate or poor scope definition may negatively influence project performance and result in the failure of projects [12]. Moreover, it may lead to a poor design basis and adversely affect projects [13]. Project scope related factors identified in this study are:

- $\quad$ sufficient project information provided by DBES;

- $\quad$ completeness and clarity of the scope definition provided by DBES;

- $\quad$ pre-project planning effort on government projects by DBES;

- $\quad$ stability of (fewer changes in) design brief or project requirement during the design phase; and

- $\quad$ management of changes in design brief at the design phase.

\subsection{Cognisant measures}

There are certain aspects that the design process should consider in order to achieve a positive outcome at a later stage. For example, value management is important "when developing the design from the project brief at the conceptual design stage, as well as in limiting any variations to those that are absolutely essential" [2]. Another important aspect that the design process of construction projects should take into account is the project life cycle view, so that projects are designed with constructability, maintainability, supportability, and the control of total cost in mind. The aspects ('cognisant measures') that the design process of construction projects should take into consideration are identified in this study as cognisance of: 
- $\quad$ time management;

- $\quad$ value management;

- $\quad$ project life cycle view;

- $\quad$ requirements and expectations of the end-users; and

- communication management.

\section{RESEARCH METHODOLOGY}

\subsection{Data collection}

This research applies a quantitative research methodology and uses a questionnaire survey to collect data. A total of 115 questionnaires were distributed to participants (units of analysis) involved in DBES building projects. The survey sample comprised five project managers, 15 architects, 15 quantity surveyors, 15 civil engineers, 15 structural engineers, 15 mechanical engineers, 15 electrical engineers, ten client ministries/departments, and ten Public Procurement and Asset Disposal Board (PPADB) registered contractors in grade E. A total of 70 completed questionnaires were returned - a response rate of $61 \%$. From the returned questionnaires, it was found that respondents who had more than five years' experience constituted $70 \%$ of the sample population, and all of the respondents had participated in DBES building projects. This indicates the validity of the sample and the data collected.

\subsection{Questionnaire design and statistical methods}

There are three parts to the questionnaire design:

i. Attributes of the respondents: years of experience, professions or training, sectors of employment.

ii. $\quad$ Factors during design phase that influence building project quality.

iii. Aspects of which design phase takes cognisance (cognisant measures).

Respondents were asked to use a Likert scale of 5 to rate each factor from 1 (very low) to 5 (very high). These ratings were used to evaluate participants involved in DBES projects against project success factors in order to identify key focus areas.

In the first part of the data analysis, the SPSS statistical software was used to determine the means and standard deviation of the attributes of the respondents, the factors, and the measures in the design phase. Moreover, a reliability test was done on the factors to determine how well the items measured a single, uni-dimensional latent construct - in this study, how well the factors could be represented as a category. The second part of the data analysis explored the differences between the independent groups (which were identified based on the attributes of the respondents) in their rating of the factors. Independent sample t-tests were used to explore any significant differences in the group means. The third part is a multivariate analysis that explored the interrelationships between the factors and the cognisant measures in the design phase.

\section{ANALYSIS OF DATA AND DISCUSSION}

\subsection{Descriptive statistics: attributes of respondents}

The frequency counts of the respondents' attributes are shown in Table 1.

The results of the frequency counts further identified two possible independent groups (of equal size) within the same attribute. Exploring the years of experience in Table 1, respondents working for 10 years or less were $58.6 \%$ of the population (i.e. $32.9 \%+25.7 \%$ ); on the other hand, respondents working more than 10 years in DBES projects were $41.4 \%$. Two independent groups with similar group sizes were identified in the total sample population as ' $\leq 10$ years' (denoted as Group 0 ) and '> 10 years' (denoted as Group 1). 
Moreover, in the profession or training attribute, those professions that were construction related (i.e. architectural and quantity surveyor services, civil and structural engineering) constituted $48.6 \%$ (denoted as Group 1), while the other professions were non-construction (i.e. electrical and mechanical engineering) and constituted 51.4\% (denoted as Group 0).

\begin{tabular}{|l|l|c|}
\hline \multicolumn{2}{|c|}{ Respondents' characteristics } \\
\hline \multirow{4}{*}{ Variables } & Frequency Counts (\%) \\
\hline \multirow{4}{*}{ Years of experience } & $1-5$ years & 32.9 \\
\cline { 2 - 3 } & 6-10 years & 25.7 \\
\cline { 2 - 3 } & $11-20$ years & 31.4 \\
\cline { 2 - 3 } & More than 20 years & 10 \\
\hline \multirow{5}{*}{ Profession or training } & Architectural services & 15.7 \\
\cline { 2 - 3 } & Quantity surveyor services & 14.3 \\
\cline { 2 - 3 } & Mechanical engineering & 20 \\
\cline { 2 - 3 } & Electrical engineering & 27.1 \\
\cline { 2 - 3 } & Civil engineering & 8.6 \\
\cline { 2 - 3 } & Structural engineering & 10 \\
\cline { 2 - 3 } Sector of employment & Others & 4.3 \\
\cline { 2 - 3 } & Public & 51.4 \\
\cline { 2 - 3 } & Private & 48.6 \\
\hline
\end{tabular}

Table 1: Frequency counts of respondents' characteristics

These two groups may be associated with participants in the two former departments, DABS \& DEMS, mentioned in the introduction. Participants working on DBES building projects who are employed in the public sector (denoted as Group 0 ) and the private sector (denoted as Group 1) are two independent groups of similar size. The above analysis is summarised in Table 2. These groups will be used in the independent samples t-test in order to compare the group means of factors.

\begin{tabular}{|c|c|c|c|}
\hline & Group code & Group description & Frequency Counts (\%) \\
\hline \multirow{2}{*}{ Years of experience } & Group 0 & $\leq 10$ years & 58.6 \\
\cline { 2 - 4 } & Group 1 & $>10$ years & 41.4 \\
\hline \multirow{2}{*}{ Profession or training } & Group 0 & Non-construction & 51.4 \\
\cline { 2 - 4 } & Group 1 & Construction & 48.6 \\
\hline \multirow{2}{*}{ Sector of employment } & Group 0 & Public & 51.4 \\
\cline { 2 - 4 } & Group 1 & Private & 48.6 \\
\hline
\end{tabular}

Table 2: Independent groups identified

\subsection{Descriptive analysis: Factors in the design phase}

As mentioned in the research methodology section, a questionnaire survey was used, and respondents were asked to rate the factors in the questionnaire to explore how DBES behaves with regard to these factors in the design phase. In Table 3, descriptive statistics of all the factors are presented. 
From Table 3, one can notice that none of the factors has a mean score above 3 (which is the mid-point on a scale of 5). This observation implies that respondents working on DBES building projects do not perform above or equal to satisfactory levels under the assessed factors.

\begin{tabular}{|c|c|c|}
\hline Variables & Means & S.D. \\
\hline \multicolumn{3}{|c|}{$\begin{array}{l}\text { Category A: Adherence to project management principles in project design phase } \\
\alpha=0.655 ; \text { mean }=2.7082 ; \text { S.D. }=0.85833\end{array}$} \\
\hline A1: Selection process of the design team & 2.83 & 1.129 \\
\hline A2: Design brief from clients & 2.83 & 1.204 \\
\hline A3: DBES's commitment to continuous quality improvement & 2.57 & 1.149 \\
\hline $\begin{array}{l}\text { A4: DBES leadership commitment to adhere to procedures and } \\
\text { specifications at the design phase }\end{array}$ & 2.80 & 0.957 \\
\hline A5: Comprehensiveness of drawings and specifications & 2.73 & 0.977 \\
\hline A6: Visibility of the total life cycle cost during the design phase & 2.63 & 1.066 \\
\hline A7: Use of lessons learned to improve the quality of designs & 2.57 & 1.124 \\
\hline \multicolumn{3}{|l|}{$\begin{array}{l}\text { Category B: Involvement of role players in project design phase } \\
\alpha=0.898 ; \text { mean }=2.7357 ; \text { S.D. }=0.75767\end{array}$} \\
\hline B1: Involvement of building contractors & 2.63 & 1.132 \\
\hline B2: Involvement of the end-users & 2.90 & 1.276 \\
\hline B3: Involvement of the management of DBES & 2.80 & 1.001 \\
\hline B4: Involvement of other stakeholders & 2.61 & 0.906 \\
\hline \multicolumn{3}{|l|}{$\begin{array}{l}\text { Category C: Project scope } \\
\alpha=0.647 ; \text { mean }=2.7600 ; \text { S.D. }=0.65106\end{array}$} \\
\hline $\begin{array}{l}\text { C1: Clarity and completeness of the project information } \\
\text { provided by DBES }\end{array}$ & 2.84 & 0.973 \\
\hline $\begin{array}{l}\text { C2: Completeness and clarity of the scope definition provided by } \\
\text { DBES }\end{array}$ & 2.81 & 0.952 \\
\hline C3: Pre-project planning effort on government projects by DBES & 2.64 & 1.077 \\
\hline $\begin{array}{l}\text { C4: Stability of (fewer changes in) design brief or project } \\
\text { requirement during the design phase }\end{array}$ & 2.70 & 0.998 \\
\hline C5: Process of management of changes in design brief & 2.80 & 1.016 \\
\hline
\end{tabular}

Table 3: Means and standard deviations of factors

There is internal consistency (or reliability) in the factors measured under each category; i.e. all the Cronbach's a values were greater than 0.6 , which indicates reliable scales. In other words, the average scores of all the means of factors under the corresponding category can represent the score of that particular category. It was found that the average score for the category Adherence to Project Management Principles (mean=2.7082) was the lowest among the three categories. Moreover, within this category, DBES's commitment to continuous quality improvement and Use of lessons learned to improve the quality of design had the two lowest means (below 2.6), and Visibility of the total life cycle cost during design phase was the third lowest of the seven factors. This finding implies that DBES's poor project quality may be the result of participants involved in DBES building projects not satisfactorily adhering to project management principles, especially with regard to the three particular factors mentioned above, during its project design phase. 


\subsection{Independent samples t-test results}

As shown earlier, there are two independent groups in each of the respondent attributes (see Table 2). We examine how these groups rate the 16 factors differently (significant at $5 \%$ level). Table 4 shows the independent samples t-test results for Group 0 and Group 1 where respondents differ in years of experience. Tables 5 and 6 show the t-test results for the other two respondents' attributes.

\begin{tabular}{|c|c|c|c|c|c|}
\hline \multirow{2}{*}{ Variables } & \multicolumn{4}{|c|}{ Years of experience } \\
\cline { 2 - 5 } & \multicolumn{2}{|c|}{$\begin{array}{c}\text { Group 0 } \\
\leq 10 \text { years }\end{array}$} & \multicolumn{2}{c|}{$\begin{array}{c}\text { Group } 1 \\
>10 \text { years }\end{array}$} & $\begin{array}{c}\text { Mean difference } \\
\text { t-test }^{\mathrm{a}} \\
\text {-value }^{\mathrm{b}}\end{array}$ \\
\cline { 2 - 6 } & Mean & S.D. & Mean & S.D. & 0.355 \\
\hline A1 & 2.98 & 1.084 & 2.62 & 1.178 & 0.178 \\
\hline A2 & 2.90 & 1.2 & 2.72 & 1.222 & 0.269 \\
\hline A3 & 2.68 & 1.192 & 2.41 & 1.086 & 0.188 \\
\hline A4 & 2.88 & 1.029 & 2.69 & 0.85 & 0.184 \\
\hline A5 & 2.8 & 0.872 & 2.62 & 1.115 & -0.045 \\
\hline A6 & 2.61 & 0.972 & 2.66 & 1.203 & 0.446 \\
\hline A7 & 2.76 & 1.157 & 2.31 & 1.039 & 0.426 \\
\hline B1 & 2.80 & 1.077 & 2.38 & 1.178 & $0.653^{*}$ \\
\hline B2 & 3.17 & 1.321 & 2.52 & 1.122 & 0.306 \\
\hline B3 & 2.93 & 0.959 & 2.62 & 1.049 & 0.225 \\
\hline B4 & 2.71 & 0.929 & 2.48 & 0.871 & 0.262 \\
\hline C1 & 2.95 & 0.893 & 2.69 & 1.072 & 0.389 \\
\hline C2 & 2.98 & 0.821 & 2.59 & 1.086 & 0.332 \\
\hline C3 & 2.78 & 1.037 & 2.45 & 1.121 & 0.253 \\
\hline C4 & 2.80 & 0.954 & 2.55 & 1.055 & $0.483^{*}$ \\
\hline C5 & 3.00 & 0.894 & 2.52 & 1.122 & \\
\hline a & & & & \\
\hline
\end{tabular}

a. mean difference between groups

b. significance at 5 percent-level ( $p$-value<0.05)

* mean difference is statistically significant at $p<0.05$

Table 4: Independent samples t-test results

In Table 4 there are no significant differences between the group means, except in factors B2 and C5. Group 0 (respondents working 10 years or less on DBES building projects) scored higher in factor B2 (involvement of the end-users) compared with Group 1 (more than 10 years). Moreover, Group 0's score on B2 is higher than the mid-point (i.e. 3 on the scale of $5)$. This may be interpreted to mean that respondents who have more years of experience working on DBES building projects know the end-users' needs and requirements from their past experience. Thus they are not necessarily eager to involve end-users during the design phase, compared with respondents who have less working experience. Another interpretation may be that respondents who have more years of working experience adopt a 'business as usual' attitude, and lack enthusiasm. On the other hand, it is assumed that respondents with fewer years of working experience are young and eager to strive for perfection by involving the end-users in the design phase. For factor C5 (process of management of changes in design brief), respondents in Group 0 again score higher than those in Group 1. This is an interesting finding, showing that respondents who have fewer years' experience actually are better at managing changes to the design brief. One of the interpretations may be that respondents are young and have learnt the most up-to-date 
project management tools and techniques, enabling them to manage the process of changes to the design brief better.

\begin{tabular}{|c|c|c|c|c|c|}
\hline \multirow{3}{*}{ Variables } & \multicolumn{5}{|c|}{ Profession or training } \\
\hline & \multicolumn{2}{|c|}{$\begin{array}{c}\text { Group } 0 \\
\text { non-construction }\end{array}$} & \multicolumn{2}{|c|}{$\begin{array}{c}\text { Group } 1 \\
\text { construction }\end{array}$} & \multirow{2}{*}{$\begin{array}{c}\text { Mean difference } \\
\text { t-test }^{\mathrm{a}} \\
p \text {-value }^{\mathrm{b}}\end{array}$} \\
\hline & Mean & S.D. & Mean & S.D. & \\
\hline $\mathrm{A} 1$ & 2.83 & 1.207 & 2.82 & 1.058 & 0.01 \\
\hline $\mathrm{A} 2$ & 2.78 & 1.198 & 2.88 & 1.225 & -0.105 \\
\hline $\mathrm{A} 3$ & 2.72 & 1.186 & 2.41 & 1.104 & 0.310 \\
\hline A4 & 2.94 & 1.013 & 2.65 & 0.884 & 0.297 \\
\hline $\mathrm{A} 5$ & 2.75 & 1.079 & 2.71 & 0.871 & 0.044 \\
\hline A6 & 2.78 & 1.124 & 2.47 & 0.992 & 0.307 \\
\hline A7 & 2.78 & 1.222 & 2.35 & 0.981 & 0.425 \\
\hline B1 & 2.78 & 1.174 & 2.47 & 1.080 & 0.307 \\
\hline B2 & 2.83 & 1.298 & 2.97 & 1.267 & -0.137 \\
\hline B3 & 2.75 & 1.025 & 2.85 & 0.989 & -0.103 \\
\hline B4 & 2.83 & 0.971 & 2.38 & 0.779 & $0.451^{*}$ \\
\hline C1 & 2.86 & 1.073 & 2.82 & 0.869 & 0.038 \\
\hline $\mathrm{C} 2$ & 2.94 & 0.924 & 2.68 & 0.976 & 0.268 \\
\hline $\mathrm{C} 3$ & 2.86 & 1.046 & 2.41 & 1.076 & 0.449 \\
\hline $\mathrm{C} 4$ & 2.72 & 0.974 & 2.68 & 1.036 & 0.046 \\
\hline $\mathrm{C} 5$ & 2.97 & 0.910 & 2.62 & 1.101 & 0.355 \\
\hline
\end{tabular}

c. mean difference between groups

d. significance at 5 percent-level ( $p$-value $<0.05)$

* mean difference is statistically significant at $p<0.05$

Table 5: Independent samples t-test results

Table 5 shows that almost all the factors are rated equally between the two groups, apart from factor B4 (involvement of other stakeholders). Respondents in Group 0 (nonconstruction; previously worked for DEMS) score higher than those in Group 1 (construction; previously worked for DABS). This may be because the type of work performed by Group 0 (electrical and mechanical engineering) is more related to operations and maintenance (e.g. planning and laying of electricity cables, or maintaining mechanical systems) compared with Group 1 (which is more architectural). During the project design phase, Group 0 needs more comprehensive information and involvement from all the stakeholders in order to make its contribution.

In Table 6, all the factors score the same between the two groups, except for factor B2 (involvement of the end-users), where the respondents in Group 0 (employed in the public sector) score higher than Group 1 (employed in private sector). Moreover, the Group 0 score is higher than the mid-point of the scale, indicating a more than satisfactory level. There is a phenomenon that corresponds to this finding. In DBES projects, during the design process, the end-users provide design needs and requirements to the DBES project participants who are employed in the public sector (e.g., government officials) and this information is then passed on to the participants in the private sector (e.g. design consultants). Thus participants from the public sector seem to be closer to the end-users because of the direct communication between them. 


\begin{tabular}{|c|c|c|c|c|c|}
\hline \multirow{3}{*}{ Variables } & \multicolumn{5}{|c|}{ Sector of employment } \\
\hline & \multicolumn{2}{|c|}{$\begin{array}{c}\text { Group } 0 \\
\text { public sector }\end{array}$} & \multicolumn{2}{|c|}{$\begin{array}{c}\text { Group } 1 \\
\text { private sector }\end{array}$} & \multirow{2}{*}{$\begin{array}{c}\text { Mean difference } \\
\text { t-test }{ }^{\mathrm{a}} \\
p \text {-value }\end{array}$} \\
\hline & Mean & S.D. & Mean & S.D. & \\
\hline $\mathrm{A} 1$ & 2.86 & 1.099 & 2.79 & 1.175 & 0.067 \\
\hline $\mathrm{A} 2$ & 2.72 & 1.210 & 2.94 & 1.205 & -0.219 \\
\hline $\mathrm{A} 3$ & 2.58 & 1.204 & 2.56 & 1.106 & 0.025 \\
\hline $\mathrm{A} 4$ & 2.81 & 1.009 & 2.79 & 0.914 & 0.011 \\
\hline A5 & 2.61 & 0.994 & 2.85 & 0.958 & -0.242 \\
\hline A6 & 2.44 & 0.998 & 2.82 & 1.114 & -0.379 \\
\hline A7 & 2.42 & 1.105 & 2.74 & 1.136 & -0.319 \\
\hline B1 & 2.42 & 1.105 & 2.85 & 1.132 & -0.436 \\
\hline B2 & 3.25 & 1.273 & 2.53 & 1.187 & $0.721^{*}$ \\
\hline B3 & 2.89 & 1.036 & 2.71 & 0.970 & 0.183 \\
\hline B4 & 2.64 & 0.899 & 2.59 & 0.925 & 0.051 \\
\hline C1 & 2.94 & 0.984 & 2.74 & 0.963 & 0.209 \\
\hline $\mathrm{C} 2$ & 2.78 & 0.959 & 2.85 & 0.958 & -0.075 \\
\hline $\mathrm{C} 3$ & 2.64 & 1.125 & 2.65 & 1.041 & -0.008 \\
\hline $\mathrm{C} 4$ & 2.72 & 0.944 & 2.68 & 1.065 & 0.046 \\
\hline $\mathrm{C} 5$ & 2.86 & 0.990 & 2.74 & 1.053 & 0.126 \\
\hline
\end{tabular}

a. mean difference between groups

b. significance at 5 percent-level ( $p$-value<0.05)

* mean difference is statistically significant at $\mathrm{p}<0.05$

Table 6: Independent samples t-test results

\subsection{Descriptive analysis: Cognisant measures in the design phase}

\begin{tabular}{|l|c|c|}
\hline Variables & Mean & S.D. \\
\hline M1: Cognisance of time management & 3.33 & 0.675 \\
\hline M2: Cognisance of value management & 3.2 & 0.844 \\
\hline M3: Cognisance of project life cycle view & 3.19 & 0.873 \\
\hline $\begin{array}{l}\text { M4: Cognisance of end users' requirements and } \\
\text { expectations }\end{array}$ & 3.71 & 0.486 \\
\hline M5: Cognisance of communication management & 3.49 & 0.583 \\
\hline
\end{tabular}

Table 7: Means and standard deviations of cognisant measures

These variables were measured using a 4-point Likert scale. As shown in Table 7, all the means are above 3 . This indicates that the project participants take all five aspects (cognisant measures) into consideration during the project design phase at a more than satisfactory level (above the mid-point of 2.5). During the design phase, project participants give the most consideration to end-users' requirements and expectations (with the mean of 3.71) and the least to project life cycle view (with the mean of 3.19). 


\subsection{Multivariate analysis: factors and measures}

The purpose of this analysis was to explore the relationships between the factors and the cognisant aspects. These relationships will indicate how the project participants' performances (with respect to a specific success factor) and their cognisance of a specific cognisant measure relate to each other. The framework of this analysis is shown in Figure 1, and the statistical results are shown in Table 8.

'Involvement of building contractors' (B1) has positive and significant impact (at a significant level of $\mathrm{p}<0.01$ ) on all cognisant measures, except for 'cognisance of end-users' requirements and expectations'. This means that the greater the involvement of building contractors, the more the project participants consider time management, value management, project life cycle view, and communication management.

'Process of managing changes in the design brief' (C5) has a negative impact (significant at $\mathrm{p}<0.05$ ) on the cognisance of time management, and a positive impact on the cognisance of value management. This result suggests that the better the project participants handled the process in managing changes in the design brief, the less important they considered time management to be.

Five factors have only slightly significant impacts $(p<0.1)$. 'Adherence to design brief from clients' (A2) has a negative impact, and 'use of lessons learned to improve the quality of designs' (A7) has a positive impact on cognisance of time management. The 'process of management of changes in design brief' (C5) has a positive impact on cognisance of time management. 'Clarity and completeness of the project information provided by DBES' (C1) has a negative impact on cognisance of the project life cycle view. 'Pre-project planning effort on government by DBES' (C3) has a positive impact on cognisance of end-users' requirements and expectations.

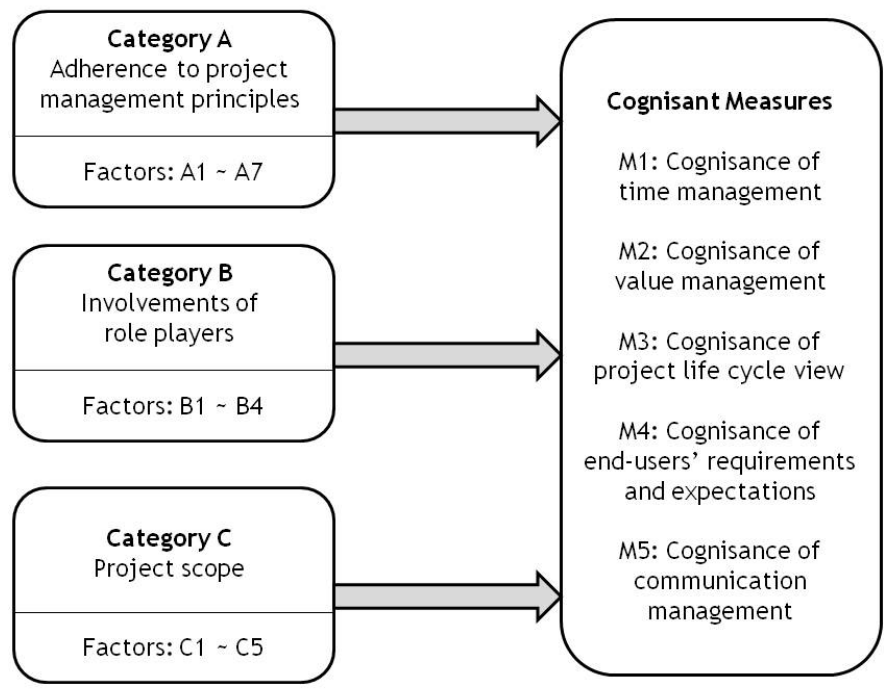

Figure 1: Research framework for multivariate analysis 


\begin{tabular}{|c|c|c|c|c|c|}
\hline \multirow{3}{*}{ Variables } & \multicolumn{5}{|c|}{ Dependent variable: cognisant measures } \\
\cline { 2 - 6 } & $M 1$ & $M 2$ & $M 3$ & $M 4$ & $M 5$ \\
\hline \multirow{2}{*}{ Constant } & $2.964^{* * *}$ & $1.343^{* *}$ & $2.016^{* * *}$ & $3.365^{* * *}$ & $2.684^{* * *}$ \\
A1 & -0.052 & -0.267 & -0.174 & -0.043 & -0.066 \\
A2 & $-0.339^{*}$ & 0.154 & 0.046 & 0.233 & 0.163 \\
A3 & -0.066 & 0.096 & -0.119 & -0.061 & 0.325 \\
A4 & 0.291 & -0.200 & 0.305 & 0.357 & -0.153 \\
A5 & -0.013 & 0.062 & 0.078 & -0.295 & 0.017 \\
A6 & -0.143 & 0.102 & 0.119 & -0.102 & 0.090 \\
A7 & $0.368^{* * *}$ & 0.302 & 0.293 & -0.072 & -0.186 \\
B1 & $0.392^{* * *}$ & $0.478^{* * *}$ & $0.454^{* * *}$ & 0.056 & $0.345^{* * *}$ \\
B2 & -0.244 & -0.104 & -0.176 & 0.033 & -0.016 \\
B3 & 0.127 & -0.078 & -0.041 & 0.057 & 0.046 \\
B4 & 0.205 & 0.073 & 0.089 & -0.255 & -0.243 \\
C1 & -0.019 & -0.003 & $-0.329^{*}$ & 0.192 & 0.072 \\
C2 & -0.046 & -0.129 & 0.124 & -0.123 & 0.224 \\
C3 & 0.204 & 0.012 & 0.014 & $0.394^{*}$ & -0.087 \\
C4 & -0.112 & 0.169 & -0.046 & -0.091 & -0.104 \\
C5 & $-0.364^{* *}$ & $0.290^{*}$ & -0.090 & 0.024 & 0.168 \\
\hline
\end{tabular}

" $p<0.10 ;{ }^{* *} p<0.05 ;{ }^{* * *} p<0.01$

Table 8: Results from regression analysis

\subsection{Multivariate analysis: categories and measures}

The purpose of this analysis was to reduce the list of factors into the three main categories and explore how these categories relate to the cognisant measures. To identify which category has the most impact on a specific cognisance measure, the three categories were entered into the regression model one at a time, as shown in the following three steps:

Model 1: Model with only Category A (Adherence to project management priniciples) Model 2: Model 1 + Category B (Involvement of role players in project design phase) Model 3: Model $2+$ Category C (Project scope)

Each time that a variable was added into the model, its associated $\Delta R^{2}$ would indicate whether the added variable was significantly accountable for the variance in the model. The statistical results are shown in Table 9.

The Variable Inflation Factor (VIF) values associated with variables in the regression models were less than 10 , indicating that serious multi-collinearity problems do not exist in these models.

Observing the three models with 'cognisance of time management' (M1) as the dependent variable, model 2 had the best fit with the addition of Category B (regression model as a whole has $\Delta \mathrm{F}$-value of 3.153 with $\mathrm{p}<0.05)$. This result suggests that, compared with the other two categories, Category $B$ has a positive and significant impact $($ at $p<0.05)$ on the cognisance of time management. 


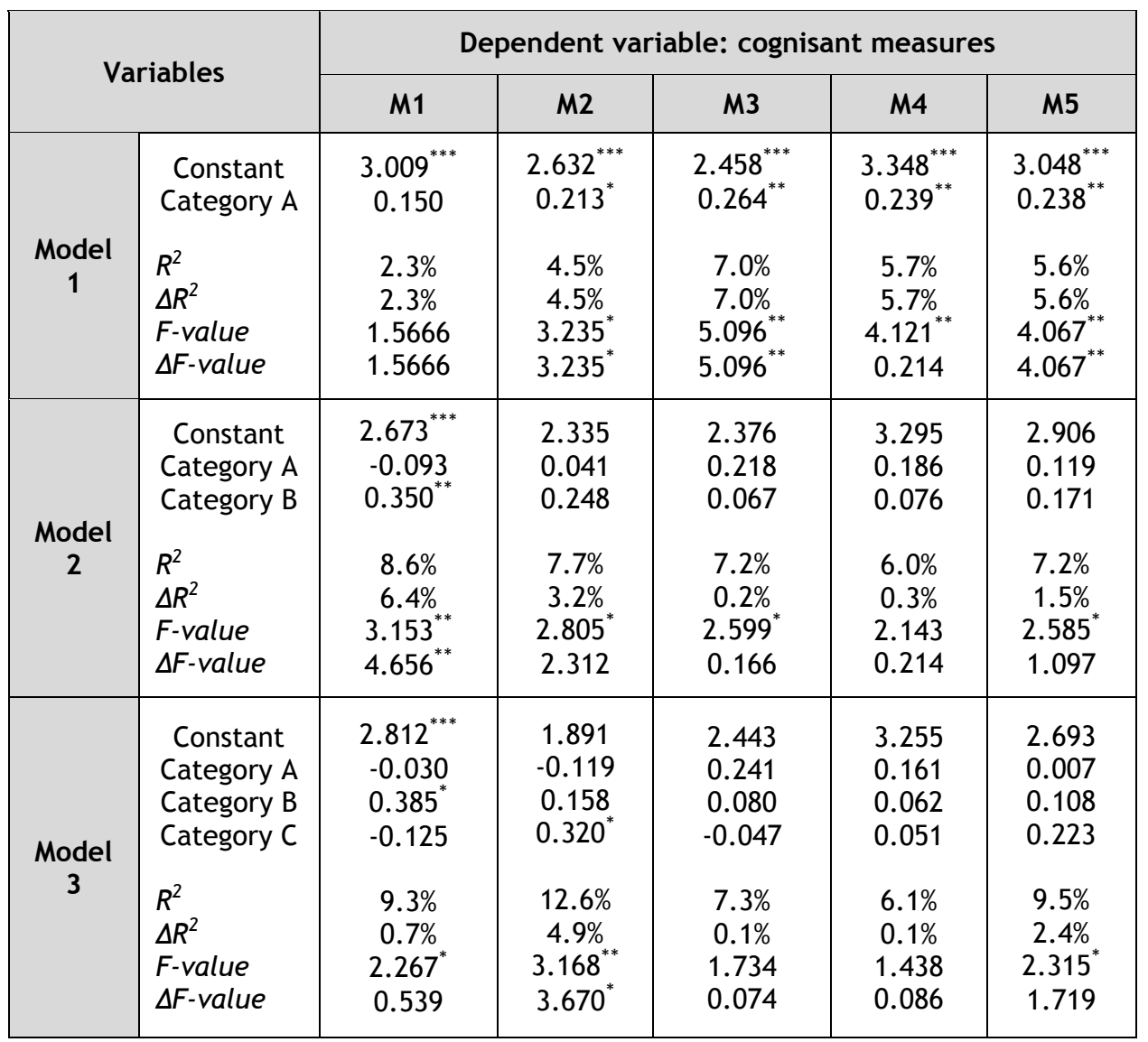

${ }^{*} \mathrm{p}<0.10 ;{ }^{* *} \mathrm{p}<0.05 ;{ }^{* * *} \mathrm{p}<0.01$

Table 9: Results from multivariate regression analysis

Of all the models with dependent variable $M 2$ (cognisance of value management), model 3 has the best fit $(\Delta \mathrm{F}$-value of 3.670 with $\mathrm{p}<0.1)$. The effect of Category $\mathrm{C}$ (project scope) in model 3 accounted for around $4.9 \%$ of the variance in $M 2$. Moreover, Category $C$ has a positive impact (significant at $\mathrm{p}<0.1$ ) on $\mathrm{M} 2$.

Model 1 has the best fit with dependent variable M3 (cognisance of project life cycle view). Addition of the other two categories did not result in any significant $\Delta \mathrm{F}$-value. Category $\mathrm{A}$ (adherence to project management principles) has a positive impact on M3 with significance at $p<0.05$. Moreover, in the analysis with the last two dependent variables (M4 \& M5), Category A has a positive impact on M4 (cognisance of end-users' requirements and expectations) and M5 (cognisance of communication management).

\section{CONCLUSION AND RECOMMENDATIONS}

In this section the most important findings are summarised and discussed, and further recommendations are suggested. 
This paper has shown statistical evidence of less than satisfactory performance by project participants during the DBES building projects design phase. That is, all factors have mean values of less than 3 (mid-point on a scale of 5 ). The key focus area that needs the most attention is Adherence to project principles during design phase (which has the lowest score out of the three categories). DBES may improve upon three factors in order to address this problem: commitment to continuous quality improvement, using lessons learned to improve quality of designs, and greater visibility of the total life cycle cost during the design phase.

From the descriptive analysis of the respondents' attributes, this study identified two independent groups within each of the attributes. Independent samples t-tests were performed to explore any significant differences in the rating of the factors.

Compared with participants with less than 10 years experience, those with longer experience were less able to manage changes in the design brief. This study assumes that respondents with fewer years of experience are younger and have learnt the most updated project management tools and techniques, possibly helping them to manage design brief change processes better. On the other hand, respondents who had longer experience may not necessarily have previous formal project management education. It is recommended that continued education be provided to those participants who have no previous knowledge of project management, with a particular focus on project management in DBES.

Independent samples t-tests explored another important issue further. Participants in DBES projects from the public sector (e.g. government officials) had direct communication with the end-user and passed on the information about design requirements to the participants in the private sector (e.g. design consultants). Information may be inaccurately interpreted and lost when transferring it from the public sector to the private sector. Inaccurate information may contribute to the reasons for poor design quality that does not meet the specifications. So it is recommended that all three parties be involved in the project design phase so that direct communication takes place between all of them (see Figure 2).

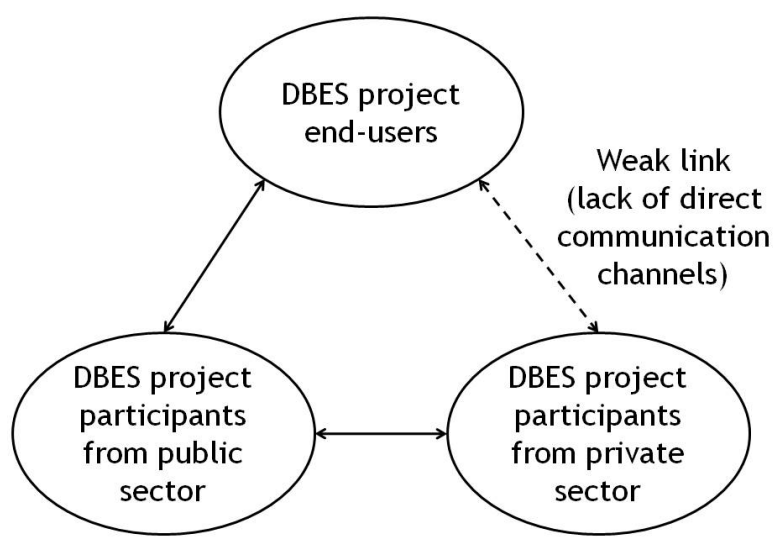

Figure 2: Inter-relationships between end-users, participants from the public sector, and participants from the private sector.

There seems to be a problem of co-ordination between the non-construction group (e.g. electrical \& mechanical services) and the construction (e.g. architectural). The statistical evidence shows this: all the stakeholders from the construction side were less involved. Not involving all the stakeholders may require correctional work after the building has been completed. For example, if an architect does not involve an electrical engineer in the design phase, the plans may locate an air-conditioning system such that the electrical 
engineer has difficulty in operating or maintaining it at a later stage. It is therefore recommended to include all stakeholders in the design phase to ensure better co-ordination in the later stages of projects (i.e. design for maintainability).

Moreover, this paper has revealed certain relationships between the success factors and the cognisant measures. The most important factor is the involvement of contractors, which has a positive influence on how well the participants take cognisance of time management, value management, and communication management. Perhaps the contractors have provided the project participants with the relevant knowledge. The involvement of the contractors has no effect on the cognisance of end-users' requirements and expectations. This may be attributed to the fact that contractors and end-users do not communicate directly. One may assume that the involvement of end-users (B2) should enhance the cognisance of their requirements and expectations (M4). However, this is not the case in DBES projects. As discussed previously, there is a weak link between the DBES project endusers and the DBES project participants from the private sector. This may contribute to the reasons for poor design quality that does not meet specifications. Thus, by bridging the missing link as recommended in Figure 2, the cognisance of end-users' requirements and expectations may be improved (see Figure 3 ).

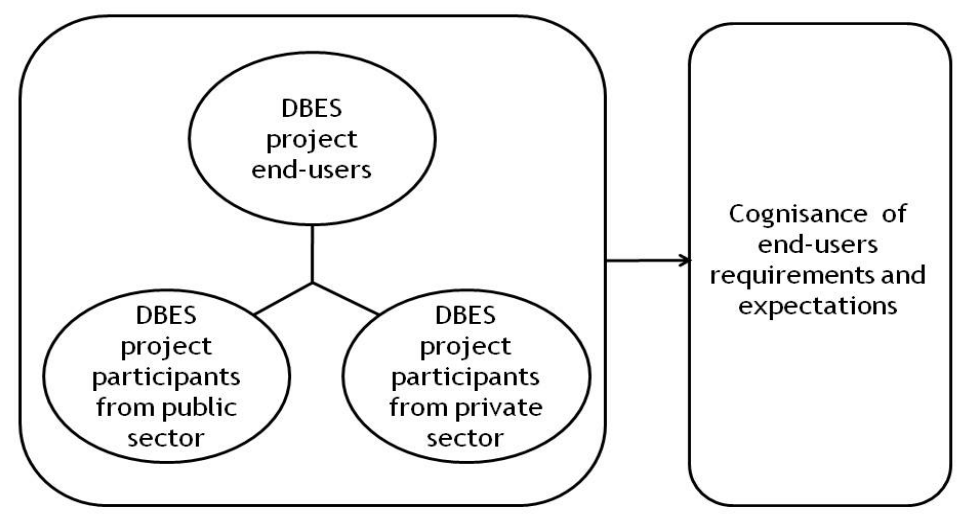

Figure 3: Direct communications amongst three parties to improve cognisance of endusers' requirements and expectations

Three negative relationships are identified in the first stage of the multivariate analysis. Although these results are only slightly significant, one can still identify the problem areas in DBES projects.

- $\quad$ The more that project participants adhere to the design brief from the clients, the less they take cognisance of time management. This finding suggests that time is subordinated to project quality. In other words, project quality is of prime importance in the case of DBES building projects; and the lower consideration of time may be the cause of delays in DBES projects.

- When project participants perform better in the process of managing changes in the design brief, they tend to take less cognisance of time management. To manage changes in the project design effectively, a configuration management (CM) approach can be used where controlling the changes to the item and its documentation is part of such an approach. When clients request changes in the design brief, one has to consider how this change may affect the time and cost of the project. Project participants know that $\mathrm{CM}$ is time-consuming, and time delays are inevitable. Therefore they may not make time a priority, considering project quality and cost to be more important. 
- $\quad$ The clearer and more complete the project information provided by DBES is, the less the project participants take cognisance of the project life cycle view. The clearer and more complete information may include the necessary tasks allocated to participants in more detail (e.g. participant $A$ has to perform task $A$ at phase $A$ of the project life cycle). Thus at each phase, participants feel that it is not necessary for them to consider or take care of other phases in the life cycle because they know in advance what their tasks are and when to perform them. All they need to do is 'follow the plan' in their allocated phase. On the other hand, if the information provided by DBES is vague or incomplete, project participants may be more uncertain about their tasks and feel that they need to see the 'whole picture' (i.e. the project life cycle view) in order to figure out where their tasks fall within the life cycle.

When comparing the three categories, Category A (adherence to project management principles) has more influence on how project participants take cognisance of the project life cycle view (M3), end-users' requirements and expectations (M4), and communication management (M5). Since project management principles are organisation-specific (i.e. they differ from one organisation to another), and since in DBES it seems that these principles take the above-mentioned aspects into account, it is recommended that these principles also take into account the other two aspects (communication management and time management) to improve DBES projects further. For example, time management helps projects to be completed within the time schedule, and communication management allows project participants 'to understand profoundly the status and level of progress in the project' [14].

Several areas for future study can be suggested. First, DBES may also be evaluated against factors during other project phases, such as the execution phase. This may point to other key focus areas to ensure better project quality. Second, this study only considers three key focus areas (the three categories) of the design phase; the framework may be extended further by exploring other focus areas as well. For example, environmental impact factors can also be taken into consideration during the project design phase. Third, similar studies may be performed in other African countries for benchmarking purposes. There may be common trends in the problem areas in the African environment, of which investors should take note.

\section{REFERENCES}

[1] Pinto, J. \& Prescott, J.E. 1990. Planning and tacticle factors in the project implementation process, Journal of Management Studies, 27(3), pp. 305-327.

[2] Chan, D.W.M. \& Kumaraswamy, M.M. 1997. A comparative study of causes of time overruns in Hong Kong construction projects, International Journal of Project Management, 15 (1), pp. 55-63.

[3] Ibbs, W., Kwak, Y.H., Ng, T. \& Odabasi, A.M. 2003. Project delivery systems and project change: Quantitative analysis, Journal of Construction Engineering and Management, 129(4), pp. 382-387.

[4] Ling, Y., Meng, F. \& Shao, Y. 2009. Research on application of constructability in project design phase under EPC mode, Construction Economy, 2009-01-028.

[5] Anderson, S. 2005. Botswana: Land of paradoxes, unpublished paper, Mercatus, George Mason University.

[6] Steyn, H. et al. 2007. Project management: A multi-disciplinary approach, $2^{\text {nd }}$ edition, FPM Publishing.

[7] Leseure, M.J. \& Brookes, N.J. 2004. Knowledge management benchmarks for project management, Journal of Knowledge Management, 8(1), pp. 103-116.

[8] Carruthers, M.C. 1999. Principles of management for quality projects, London International Thomson Business Press.

[9] Kloppenborg, T.J. \& Petrick, J.A. 2002. Managing project quality, Management Concept Inc. 
[10] Darwish, M.I. et al. 2007. Factors affecting design and documentation quality in the construction industry, Construction Contracting Administration.

[11] Chan, A.P.C., Scott, D. \& Chan, A.P.L. 2004. Factors affecting the success of a construction project, Journal of Construction Engineering and Management, 130(1), pp. 153-155.

[12] Dumont, P., Gibson, G. \& Fish, J. 1997. Scope management using the project definition rating index (PDRI), ASCE Journal of Management in Engineering, 13(5), pp. $54-60$.

[13] Cho, C.-S \& Gibson, G.E., Jr. 2001. Building project scope definition using project definition rating index, Journal of Architectural Engineering, 7(4), pp. 115-125.

[14] Hameri, A.-P. 1997. Project management in a long-term and global one-of-a-kind project, International Journal of Project Management, 15(3), pp. 151-157. 
